\title{
EMBRIOLOGI DALAM AL-QUR'AN: KAJIAN PADA PROSES PENCIPTAAN MANUSIA
}

\section{Kiptiyah}

Fakultas Sains dan Teknologi Universitas Islam Negeri (UIN) Malang

Jalan Gajayana No. 50 Malang 65144 Telp. 0341-551354 Faks. 0341-572533

\begin{abstract}
Researchers have studied human embryology for many centuries, but there's no yet detailed appropriate explanation about the process of human creation: even the told theory sometimes digress from the fact. This caused by the limitation of human science and knowledge. In Surat Yusuf verse 3 it is explained "We do relate unto thee the most beautiful of stories, in that We reveal to thee this (portion of the) Qur'an: before this, thou too was among those who knew it not.

Al-Qur'an explains in detailed how Allah creates human. Allah said in Surat al-Mu'minuun, verse 12-14. Man We did create from a quintessence (of clay); then We placed him as (a drop of) sperm in a place of rest, family fixed; then We made the sperm into a clot of congealed blood; then of that clot We made a (fetus) lump; then We made out of that lump bones and clothed the bones with flesh; then We developed out of it another creature. So blessed be God, the best to create!

Thirteen centuries after al-Qur'an released, there were researchers on embryology. The result of those researchers proved the legitimate concepts of embryology in al-Qur'an. Based on those findings, this research's theme is: "Embryology inside al-Qur'an: the study of how human's creation.
\end{abstract}

Ulul Albab, Vol. 8 No. 2, 2007 
This reseach discusses the creation process of the first human (Adam a. s) and the creation process of humans after based on the embryology concept revealed in al-Qur'an by using integrated science as the approach. By the released of this research, writer wishes may Allah swt pours this overflowing blesses and makes the writer as a grateful person.

May Allah, the Most Holly Owner of unlimited knowledge, enhances reciprocation for those whose ijtihad's results are right and He will keep on giving reciprocation for those whose ijtihad's results are wrong as reward for their effort.

Key words: embriologi, manusia, al-Qur'an

\section{Pendahuluan}

Manusia merupakan makhluk ciptaan Allah swt yang paling mulia, baik dilihat dari segi bentuk, kepribadian, akal, pikiran, perasaan, dan sebagainya. Berbeda dengan makhluk yang lain, meskipun memiliki kehidupan tetapi tidak memilik sifat-sifat seperti manusia. Sebagai makhluk yang paling mulia, ternyata bahan dasar yang dipakai dalam menciptakan manusia adalah tanah. Maha Besar Allah swt, pencipta yang paling baik. Hal ini sesuai dengan firman Allah swt:

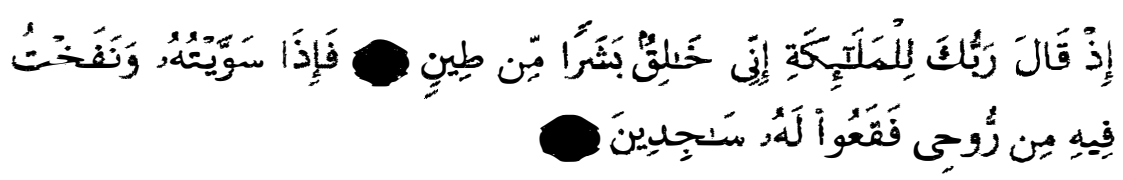

"(Ingatlah) ketika Tuhanmu berfirman kepada malaikat, sesunguhnya Aku menciptakan manusia dari tanah. Apabila telah Ku sempurnakan kejadiannya dan Kutiupkan kepadanya ruh (ciptaan)Ku; maka hendaklah kamu tersungkur dengan bersujud kepadanya." (QS. Shaad: 71-72). 
Dalam ayat yang lain juga dijelaskan:

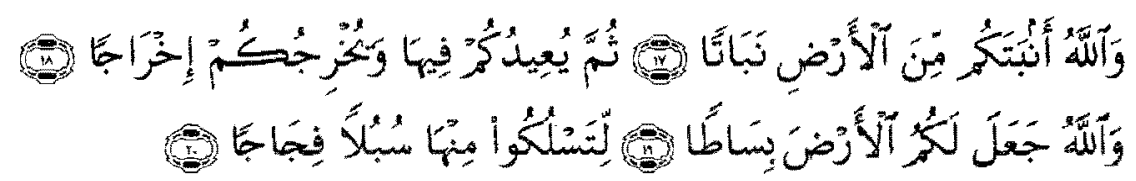

"Allah menumbuhkan kamu dari tanah dengan sebaik-baiknya, kemudian Dia mengembalikan kamu ke dalam tanah dan mengeluarkan kamu (dari padanya pada hari kiamat) dengan sebenarnya-benarnya. Allah menjadikan bumi untukmu sebagai hamparan, supaya kamu menjalani jalan-jalan yang luas di bumi itu" (QS. Nuh: 17-20).

Ayat tersebut menjelaskan bahwa proses (tahapan) penciptaan manusia melibatkan tanah (kerak bumi) sebagai bahan dasar, penyempurnaan dan proses pembentukan, serta ditiupkan ruh Allah swt. Proses tersebut merupakan salah satu tahapan pembentukan manusia dari tanah yang merupakan salah satu unsur bumi, sebagaimana yang tersurat di dalam ayat al-Qur'an tentang proses penciptaan manusia.

Bumi merupakan tempat berpijaknya manusia. Manusia diciptakan dari tanah dan akan kembali ke tanah (bumi). Tanah (kerak bumi) mengandung berbagai macam unsur, antara lain Oksigen $(\mathrm{O})(46,6 \%)$, Silikon (Si) $(27,7 \%)$, Aluminium (Al) $(8,1 \%)$, Besi (Fe) $(5,0 \%)$, Kalsium (Ca) $(3,6 \%)$, Natrium (Na) (2,8\%), Kalium (K) (2,6\%), dan Magnesium (Mg) (2,1\%) (Krauskopf, 1993: 414-415). Unsur-unsur inilah yang membentuk fisik manusia. Fisik yang terbentuk akan disempurnakan Allah swt dengan bentuk yang paling mulia di antara makhluk-makhluk yang lain. Kemudian ditiupkan roh Allah swt ke dalamnya.

Tanah merupakan bagian dari kerak bumi yang terdiri dari beberapa partikel, antara lain seperti silikat dan alumunium. Berdasarkan unsur-unsur dan partikel-partikel yang ditemukan di dalam tanah, diduga bahwa tanah yang dipakai sebagai bahan dasar penciptaan manusia adalah tanah liat. Tanah liat merupakan partikel silikat berair yang berdiameter kurang dari 4 mikrometer (Krauskopf, 1993: 414-415). Tanah liat mengandung leburan

Ulul Albab, Vol. 8 No. 2, 2007 
silikat dan alumunium yang halus. Unsur-unsur seperti, silikon, oksigen, dan alumunium adalah unsur yang banyak komposisinya di kerak bumi. Tanah liat merupakan hasil dari proses senyawa batuan silikat oleh asam karbon, tetapi sebagian dihasilkan dari aktivitas panas bumi. Tanah liat mempunyai gumpalan keras saat kering dan lengket apabila basah terkena air.

Sebagaimana Firman Allah swt:

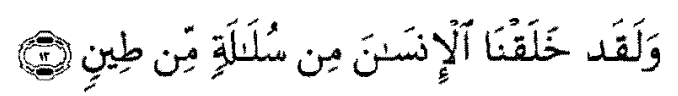

"Dan sesungguhnya Kami telah menciptakan manusia dari suatu saripati (berasal) dari tanah" (QS. al-Mu'minuun: 12).

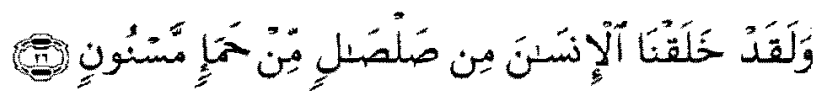

"Dan sesungguhnya Kami telah menciptakan manusia (Adam as) dari tanah liat kering (yang berasal) dari tanah hitam yang diberi bentuk" (QS. al-Hijr: 26).

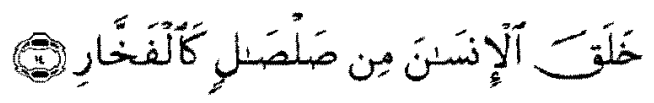

"Dia menciptakan manusia dari tanah kering seperti tembikar" (QS. al-Rahmaan: 14)

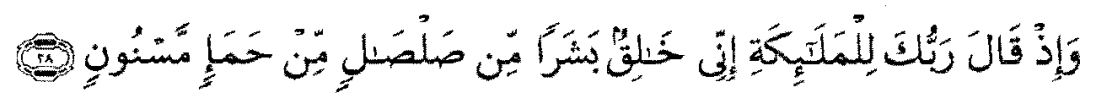

Dan (ingatlah) ketika Tuhanmu berfirman kepada malaikat, "Sesungguhnya Aku akan menciptakan seorang manusia dari tanah liat kering (yang berasal) dari lumpur hitam yang diberi bentuk" (QS. al-Hijr:28)

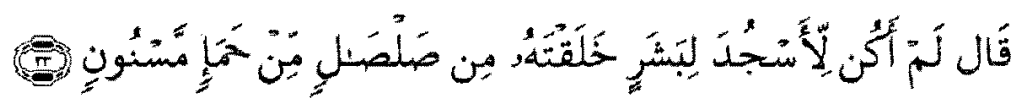

Berkata Iblis, "Aku sekali-kali tidak akan sujud kepada manusia yang Engkau telah menciptakannya dari tanah liat kering (yang berasal) dari lumpur hitam yang diberi bentuk" (QS. al-Hijr: 33). 
Ayat-ayat di atas menggambarkan ketika Allah swt memerintahkan iblis untuk sujud kepada Adam as. Ini membuktikan bahwa manusia adalah makhluk ciptaan Allah swt yang paling mulia sehingga iblis harus bersujud kepadanya.

\section{Metode Penelitian}

Penelitian ini merupakan penelitian kepustakaan dengan metode tematik. Penelitian ini dilakukan dengan mengumpulkan data dari alQur'an yang ditafsirkan dengan berbagai referensi sains secara terintegrasi.

\section{Pembahasan}

\section{Kandungan Zat Kimia dalam Tanah Liat dan Tubuh Manusia}

\section{Silikat}

Silikat merupakan suatu senyawa yang mengandung satu anion dengan satu atau lebih atom silikon pusat yang dikelilingi oleh ligan elektronegatif. Jenis silikat yang sering ditemukan umumnya terdiri dari silikon dengan oksigen sebagai ligannya. Anion silikat dengan muatan listrik negatif harus mendapatkan pasangan kation lain untuk membentuk senyawa bermuatan netral. Silika atau silikon dioksida, $\mathrm{SiO}_{2}$, sering dianggap sebagai silikat, walaupun senyawa ini tidak bermuatan negatif dan tidak memerlukan ion pasangan. Silikat ditemukan di alam dalam bentuk mineral kuarsa.

\section{Oksigen}

Oksigen atau zat asam merupakan unsur kimia yang mempunyai lambang $\mathrm{O}_{2}$. Di bumi, oksigen biasanya berikatan dengan unsur lain dalam ikatan kovalen dan ionik. Oksigen (juga disebut molekul oksigen, $\mathrm{O}_{2}$ ) pertama kali muncul di bumi dalam jumlah yang signifikan selama era Paleoproterozoik (antara 2,5 milyar tahun dan 1,6 milyar tahun yang lalu) sebagai produk dari aktivitas metabolik dari organisme anaerob awal (bakteri).

Ulul Albab, Vol. 8 No. 2, 2007 
Berlimpahnya oksigen bebas pada atmosfir bumi dan peningkatan konsentrasinya hingga seperti saat ini disebabkan oleh sintesis organisme fotosintetik. Sekitar 75\% dihasilkan oleh alga dan mikroorganisme hijau di laut, dan seperempat lagi oleh tumbuhan di daratan.

Oksigen adalah satu dari dua komponen utama udara. Oksigen dihasilkan oleh tanaman selama fotosintesis, dan diperlukan untuk pernapasan aerobik pada hewan dan manusia. Istilah oksigen ini dikemukakan oleh Antoine Lavoisier pada abad ke-18.

\section{Aluminium}

Keberadaan aluminium di bumi melimpah. Aluminium berperan sebagai konduktor listrik yang baik sebagai panas dan tahan korosi (karat).

\section{Asam Karbon}

Asam karbon terdiri dari beberapa unsur, yaitu asam amino, karbon, senyawa biomolekul, senyawa organik, asam ricinoleat, asam lemak, karbondioksida, protein pembawa acil (ACP), asam linolenat, asam lemak jenuh, dan asam stearat. Unsur-unsur yang ada di dalam asam karbon ini mempunyai sifat dan kegunaan yang spesifik dalam mendukung metabolisme tubuh.

\section{Asam Amino}

Asam amino adalah senyawa organik yang memiliki gugus fungsional karboksil dan amina. Gugus karboksil memberikan sifat asam dan gugus amina memberikan sifat basa. Dalam bentuk larutan, asam amino bersifat amfoterik, artinya cenderung menjadi asam pada larutan basa dan menjadi basa pada larutan asam. Perilaku ini terjadi karena asam amino mampu menjadi zwitter ion. Asam amino termasuk golongan senyawa yang paling banyak dipelajari karena salah satu fungsinya sangat penting dalam kehidupan organisme, yaitu sebagai penyusun protein. 
Protein tersusun dari berbagai asam amino yang masing-masing dihubungkan dengan ikatan peptida. Meskipun demikian, pada awal pembentukannya protein hanya tersusun dari 20 asam amino yang dikenal sebagai asam amino penyusun protein (proteinogenik). Asam-asam amino inilah yang disandi oleh RNA sebagai kode genetik (Tamarin, 2002: 281282). Karbon (C), Hidrogen (H), Oksigen (O), dan Nitrogen (N) merupakan bahan makronutrien yang membentuk protein. Protein berperan sebagai sumber energi. Senyawa protein berperan dalam membantu kontraksi otot dan sebagai antibodi yaitu senyawa yang berperan dalam sistem pertahanan tubuh terhadap serangan penyakit (Sudarmadji, dkk., 1989: 119-120).

Asam amino esensial penyusun protein, yaitu glisin, alanin, valin, leusin, isoleusin, serin, treonin, asam aspartat, asam glutamat, asparagin, glutamin, lisin, arginin, histidin, sistein, metionin, prolin, fenilalamin, tirosin, dan triptofan. Fungsi biologis asam amino adalah sebagai berikut:

1. penyusun protein, termasuk enzim;

2. kerangka dasar sejumlah senyawa pen ing dalam metabolisme (terutama vitamin, hormon, dan asam nukleat); dan

3. pengikat ion logam penting yang diperlukan dalam reaksi enzimatik (Tamarin, 2002).

Asam amino diperlukan oleh makhluk hidup termasuk manusia sebagai penyusun protein atau sebagai kerangka molekul-molekul penting. Asam amino disebut esensial bagi suatu spesies organisme jika spesies tersebut memerlukannya tetapi tidak mampu memproduksi sendiri atau selalu kekurangan asam amino yang bersangkutan. Untuk memenuhi kebutuhan ini, spesies tersebut harus memasoknya dari luar (melalui makanan). Bagi manusia, ada beberapa asam amino esensial yang harus dipenuhi dari diet sehari-hari, yaitu isoleusin, leusin, lisin, metionin, fenilalanin, treonin, triptofan, dan valin. Histidin dan Arginin disebut sebagai setengah esensial karena tubuh manusia dewasa sehat mampu memenuhi kebutuhannya.

Ulul Albab, Vol. 8 No. 2, 2007 


\section{Karbon}

Karbon merupakan bagian yang penting dalam kehidupan di bumi. Karbon berperan penting dalam struktur, biokimia, dan nutrisi pada semua sel makhluk hidup. Dalam kehidupan di bumi karbon berperan penting dalam siklus karbon. Karbon dipindahkan di dalam biosfersebagai makanan, misalnya buah-buahan. Termasuk di dalamnya adalah pemanfaatan material organik yang mati oleh jamur dan bakteri untuk fermentasi atau penguraian. Sebagian karbon meninggalkan biosfer melalui pernapasan. Ketika tersedia oksigen, pernapasan terjadi dan melepaskan karbon dioksida ke udara atau air (bagi hewan air) di sekitarnya. Aktivitas ini terjadi pada manusia saat melakukan pernapasan. Karbon terdapat pada semua makhluk hidup dan merupakan dasar kimia organik (Janzen, 2004: 104). Senyawa karbon juga terdapat di dalam tanah (kerak bumi).

Tanah merupakan unsur kerak bumi sebagai bahan dasar penciptaan manusia yang menuntut kebutuhan jasmani dan rohani, disertai dengan iman. Dimensi-dimensi ini merupakan satu kesatuan untuk mencapai kesempurnaan, sebagaimana firman Allah swt:

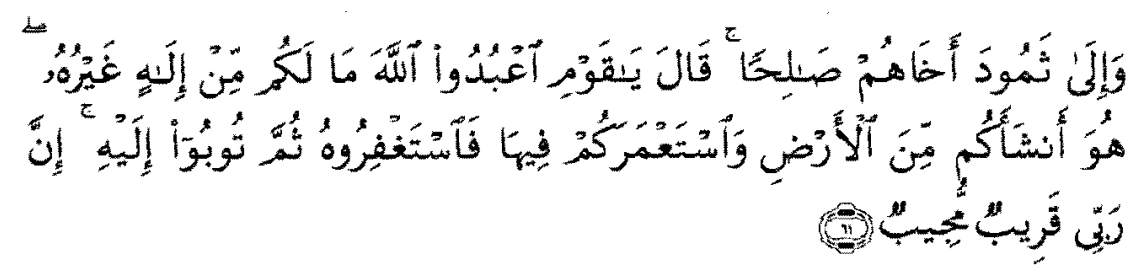

"Dia telah menciptakan kamu dari bumi (tanah) dan menjadikan kamu pemakmurnya, karena itu mohonlah ampunan-Nya, kemudian bertobatlah kepada-Nya. Sesungguhnya Tuhanku amat dekat (rahmatNya) lagi memperkenankan (doa hamba-Nya)." (QS. Huud: 61).

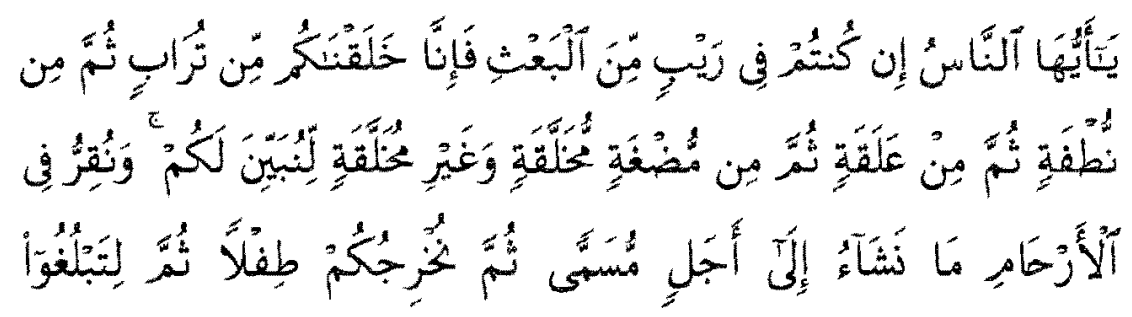

Ulul Albab, Vol. 8 No. 2, 2007 


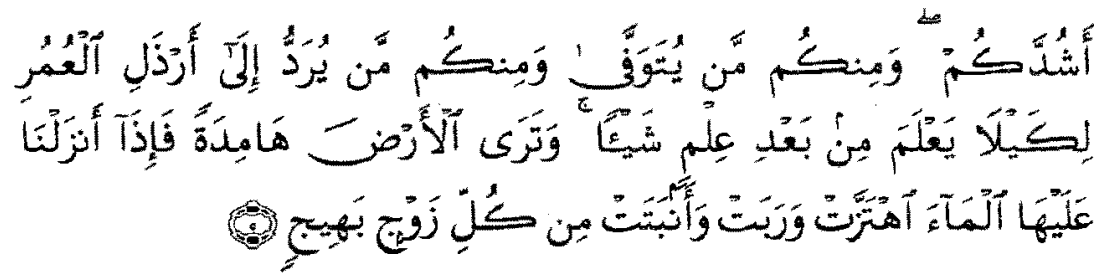

"Hai manusia, jika kamu dalam keraguan tentang kebangkitan (dari kubur), Maka (ketahuilah) sesungguhnya Kami telah menjadikan kamu dari tanah, kemudian dari setetes mani, kemudian dari segumpal darah, kemudian dari segumpal daging yang sempurna kejadiannya dan yang tidak sempurna, agar kami jelaskan kepada kamu dan kami tetapkan dalam rahim, apa yang Kami kehendaki sampai waktu yang sudah ditentukan, kemudian Kami keluarkan kamu sebagai bayi, kemudian (dengan berangsur-angsur) kamu sampailah kepada kedewasaan, dan di antara kamu ada yang diwafatkan dan (adapula) di antara kamu yang dipanjangkan umurnya sampai pikun, supaya dia tidak mengetahui lagi sesuatupun yang dahulunya telah diketahuinya. Dan kamu lihat bumi ini kering, kemudian apabila telah Kami turunkan air di atasnya, hiduplah bumi itu dan suburlah dan menumbuhkan berbagai macam tumbuh-tumbuhan yang indah"(QS. al-Hajj: 5).

Air

Air merupakan unsur penting dalam penciptaan tubuh manusia. Lebih dari 70\% tubuh makhluk hidup terdiri dari air. Air berperan dalam membantu melarutkan berbagai nutrien dan mengalirkannya ke seluruh tubuh. Air juga membantu mengeluarkan pembuangan akibat proses metabolisme di dalam tubuh.

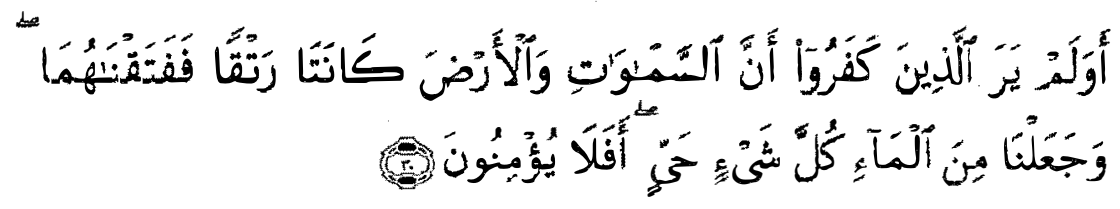

"Dan apakah orang-orang yang kafir tidak mengetahui bahwasannya langit dan bumi itu keduanya dahulu adalah suatu yang padu, kemudian Kami pisahkan antara keduanya. Dan dari air Kami jadikan segala sesuatu yang hidup. Maka, mengapakah mereka tiada juga beriman?" (QS. al-Anbiyaa': 30).

Ulul Albab, Vol. 8 No. 2, 2007 
Dari bahan-bahan dasar yang terkandung di dalam tanah liat seperti apa yang telah dipaparkan kemudian dicampur dengan air yang bertujuan agar tanah liat tersebut lebih mudah untuk dibentuk. Pada ayat-ayat di atas menggambarkan dan menjelaskan bahwa manusia dibentuk dari tanah (QS. Huud: 61, al-Hajj: 5, dan al-Mu'minuun: 12), tanah liat kering seperti tembikar (QS. ar-Rahman: 14), dan tanah liat kering yang berasal dari lumpur hitam yang diberi bentuk (QS.al-Hijr: 28). Berdasarkan hasil penelitian pada abad ke-20 yang menunjukkan bahwa tubuh manusia juga tersusun dari suatu zat yang ditemukan di dalam tanah yang disebut sebagai karbon (dalam ilmu kimia dilambangkan dengan huruf $\mathrm{C}$ ).

Air yang dipakai sebagai bahan pemberi bentuk tubuh manusia bersama dengan tanah liat diduga berasal dari air tawar maupun air laut. Air tawar merupakan suatu bahan pelarut yang baik, sedangkan air laut merupakan air yang mengandung kadar garam yang berperan sebagai elektrolit dalam membantu transpor natrium dan kalium di dalam tubuh manusia. Hal ini dapat dibuktikan melalui hasil peneliwan pada abad ke-20 menggambarkan tentang perbandingan komposisi kimia yang terkandung di dalam tubuh manusia dengan air laut dan kerak bumi, seperti yang tercantum pada tabel berikut:

Ulul Albab, Vol. 8 No. 2, 2007 
Tabel 1. Perbandingan Komposisi Kimia di dalam Tubuh Manusia dengan Unsur-unsur yang Terkandung di dalam Air Laut dan Kerak Bumi (Dalam \%)

\begin{tabular}{|c|c|c|c|c|c|}
\hline \multicolumn{2}{|c|}{ (T) Tub Marnista } & \multicolumn{2}{|c|}{ 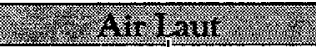 } & \multicolumn{2}{|c|}{ O. Kerak Bum } \\
\hline $\mathrm{H}$ & 63 & $\mathrm{H}$ & 66 & $\mathrm{O}$ & 47 \\
\hline $\mathrm{O}$ & 25,5 & $\mathrm{O}$ & 33 & $\mathrm{Si}$ & 28 \\
\hline $\mathrm{C}$ & 9,5 & $\mathrm{Cl}$ & 0,33 & $\mathrm{Al}$ & 7,9 \\
\hline $\mathrm{N}$ & 1,4 & $\mathrm{Na}$ & 0,28 & $\mathrm{Fe}$ & 4,5 \\
\hline $\mathrm{Ca}$ & 0,31 & $\mathrm{Mg}$ & 0,33 & $\mathrm{Ca}$ & 3,5 \\
\hline $\mathrm{P}$ & 0,22 & $\mathrm{~S}$ & 0,017 & $\mathrm{Na}$ & 2,5 \\
\hline $\mathrm{Cl}$ & 0,03 & $\mathrm{Ca}$ & 0,006 & K & 2,5 \\
\hline $\mathrm{K}$ & 0,06 & $\mathrm{~K}$ & 0,006 & $\mathrm{Mg}$ & 2,2 \\
\hline$S$ & 0,05 & $\mathrm{C}$ & 0,0014 & $\mathrm{Ti}$ & 0,46 \\
\hline $\mathrm{Na}$ & 0,03 & $\mathrm{Br}$ & 0,0005 & $\mathrm{H}$ & 0,22 \\
\hline $\mathrm{Mg}$ & 0,01 & \multirow{2}{*}{\multicolumn{2}{|c|}{ Lainnya $<0,1$}} & $\mathrm{C}$ & 0,19 \\
\hline \multicolumn{2}{|c|}{ Lainnya $<0,01$} & & & \multicolumn{2}{|c|}{ Lainnya $<0,1$} \\
\hline
\end{tabular}

Sumber: Biology: an Application of Life, 1972 dalam Randall, dkk (1997: 37-40)

Dari tabel di atas dapat diketahui bahwa air laut merupakan bagian dari kerak bumi. Keduanya secara bersama-sama membentuk komposisi kimia penyusun tubuh manusia. Selanjutnya dalam proses siklus kehidupan di bumi, unsur-unsur bahan kimia yang terdapat di dalam tanah tersebut akan diserap oleh akar tumbuh-tumbuhan untuk melangsungkan serangkaian proses kehidupan. Ini dapat diamati pada tumbuh-tumbuhan yang di dalam tubuhnya juga mengandung zat-zat kimia. Menurut Sudarmadji, dkk (1989: 119-120) di dalam tubuh tumbuhan mengandung kalsium (pada kacang-kacangan dan buah-buahan), phosphor (terdapat pada kacang-kacangan), zat besi (ditemukan pada tepung gandum, buahbuahan, dan sayur-sayuran), natrium (terkandung di dalam garam dapur), kalium (buah-buahan dan sayur-sayuran), magnesium (kacang-kacangan, sayur-sayuran, dan buah-buahan), sulfur (kacang-kacangan), cobalt (sayursayuran dan buah-buahan), dan zink (ditemukan pada bahan makanan hasil laut) (Sudarmadji, dkk., 1989: 120). Bahan-bahan kimia tersebut dapat diterima oleh tubuh manusia. Hal ini dapat dipahami karena di dalam tubuh

Ulul Albab, Vol. 8 No. 2, 2007 
manusia telah mengenali dan mengatur bahan-bahan kimia tersebut sesuai dengan kebutuhan. Jika keberadaan bahan-bahan tersebut berlebihan, maka tubuh akan mengeluarkannya melalui ginjal dan selanjumya keluar bersama air kencing; dengan demikian kondisi tubuh selalu dalam keadaan seimbang. Dengan adanya penemuan tentang komposisi zat kimia penyusun tubuh manusia tersebut, merupakan bukti bahwa al-Qur'an merupakan wahyu yang diturunkan Allah swt kepada Nabi Muhammad saw yang dibuktikan oleh manusia sepanjang jaman. Maha suci Allah yang telah mewahyukan al-Qur'an sebagai sumber dari segala sumber ilmu. Maha besar Allah swt, semua makhluk hidup bersujud dan mensucikan keesaan-Nya yang telah menciptakan segala sesuatu.

\section{Proses Penciptaan Manusia}

Allah swt mengutus Nabi Muhmmad saw sebagai utusan untuk seluruh alam semesta. Nabi Muhammad saw diutus ke muka bumi agar menjadi petunjuk dan rahmatbagi alam seniesta, sebagaimana firman Allah swt dalam al-Qur'an:

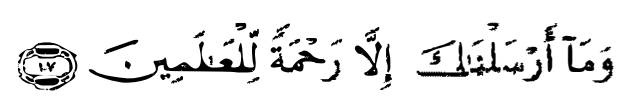

"Dan tiadalah Kami mengutus kamu, melainkan untuk (menjadi) rahmat bagi semesta alam". (QS. al-Anbiya': 107)

Demikianlah, Nabi Muhammad saw sebagai utusan Allah swt untuk masyarakat di gurun pasir sebagaimana Beliau juga diutus bagi para ilmuwan masa kini di laboratorium modernnya. Nabi Muhammad saw adalah utusan Allah swt kepada seluruh umat manusia untuk segala zaman. Berbeda dengan Nabi muhanmmad saw, setiap nabi atau rasul hanya diutus khusus untuk kaumnya. Sebagaimana firman Allah swt:

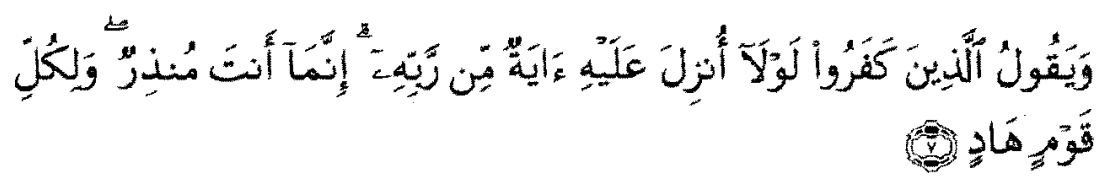

Ulul Albab, Vol. 8 No. 2, 2007 
"Orang-orang yang kafir berkata: "Mengapa tidak diturunkan kepadanya (Muhammad) suatu tanda (kebesaran) dari Tuhannya?" Sesungguhnya kamu hanyalah seorang pemberi peringatan; dan bagi tiap-tiap kaum ada orang yang memberi petunjuk" (QS. al-Ra'du: 7).

Risalah Nabi Muhammad saw merupakan utusan untuk seluruh umat manusia, sehingga Allah swt memberikan bukti bagi risalah Nabi Muhammad saw, yaitu sebuah bukti yang berbeda dengan bukti-bukti yang diberikan kepada rasul-rasul sebelumnya. Bukti-bukti para rasul terdahulu hanya dapat dilihat dan dirasakan oleh orang pada zamannya, yang didukung dengan mu'jizat untuk menyadarkan keimanan kaumnya. Namun demikian, Nabi Muhammad saw ditakdirkan untuk menjadi nabi terakhir hingga hari pembalasan. Allah swt menganugerahkan kepada Nabi Muhammad saw mu'jizat abadi sebagai bukti kenabiannya.

Mu'jizat NabiMuhammad saw sampai sekarang masih dijadikan sebagai sumber dari segala sumber ilmu yang mengungkap kebenaran. Hal ini berbeda dengan mu'jizat para nabi sebelumnya. Jika kita bertanya kepada kaum Yahudi atau Nasrani untuk menunjukkan mu'jizat Nabi Musa as atau Nabi Isa as, mereka akan menyampaikan bahwa tidak ada kuasa bagi manusia untuk mendemonstrasikan kembali mu'jizat-mu'jizat itu lagi sekarang. Tongkat Nabi Musa as tidak akan dapat diciptakan lagi, demikian halnya Nabi Isa as, tak akan lagi dimintai tolong untuk membangkitkan orang dari kematian. Bagi orang-orang muslim, mu'jizat-mu'jizat ini telah tercatat dalam sejarah dan telah tercantum di dalam al-Qur'an. Hal ini berbeda dengan mu'jizat Nabi Muhammad saw yang masih dapat ditunjukkan dan tetap terjaga sampai hari akhir yaitu kitab suci al-Qur'an. Al-Qur'an merupakan kitab yang terbuka bagi siapa saja untuk mempelajari isi kebenarannya. Allah swt berfirman di dalam al-Qur'an:

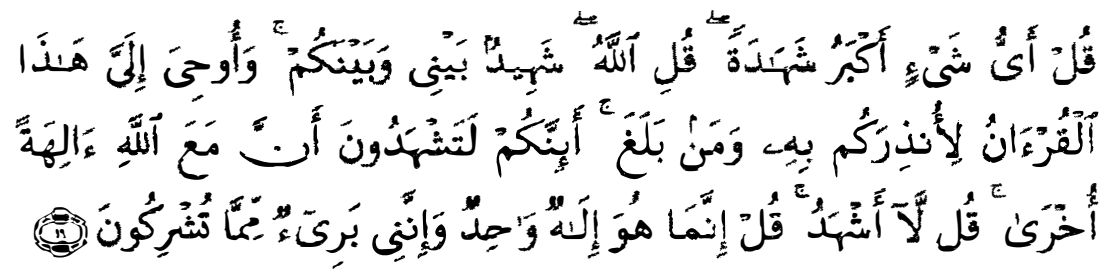

Ulul Albab, Vol. 8 No. 2, 2007 
Katakanlah: "Siapakah yang lebih kuat persaksiannya?" Katakanlah: "Allah". Dia menjadi saksi antara aku dan kamu. Dan al-Quran ini diwahyukan kepadaku supaya dengan dia, aku memberi peringatan kepadamu dan kepada orang-orang yang sampai al-Quran (kepadanya). Apakah sesungguhnya kamu mengakui bahwa ada tuhan-tuhan lain di samping Allah?" Katakanlah: "Aku tidak mengakui." Katakanlah: "Sesungguhnya Dia adalah Tuhan yang Maha Esa dan sesungguhnya aku berlepas diri dari apa yang kamu persekutukan (dengan Allah)" (QS. al-An'am: 19).

Dalam al-Qur'an terkandung ilmu pengetahuan yang merupakan dasar dan sumber kebenaran, Maha suci Allah dalam firman-Nya;

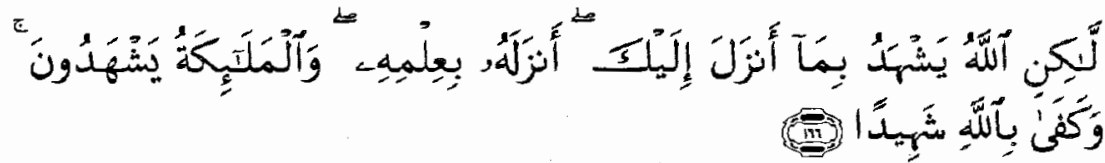

“(mereka tidak mau mengakui yang diturunkan kepadamu itu), tetapi Allah mengakui al-Quran yang diturunkan-Nya kepadamu. Allah menurunkannya dengan ilmu-Nya; dan malaikat-malaikat pun menjadi saksi (pula). Cukuplah Allah yang mengakuinya"(QS. al -Nisaa': 166).

Dengan demikian para ilmuwan dan peserta didiknya dapat menggunakan kesempatan untuk melakukan penelitian (termasuk proses penciptaan manusia) melalui konsep embriologi yang bersumber pada al-Qur'an. Sebelum para ilmuwan mempelajari dan melakukan penelitian tentang embrio, empat belas abad yang lalu al-Qur'an telah dapat memaparkan proses terbentuknya embrio dan fase-fase perkembangannya secara detail dan akurat, sedangkan embriologi, baru berkembang pada abad ke-19. Di dalam al-Qur'an telah dijelaskan mengenai perkembangan manusia, walaupun hampir seluruh pengetahuan ini belum ditemukan hingga beberapa abad kemudian. Ini membuktikan bahwa Nabi Muhammad saw adalah utusan Allah swt dengan mu'jizatnya yang menjadi dasar riset para ilmuwan modern. Allah swt berfirman di dalam al-Qur'an berkenaan dengan tahap-tahap penciptaan manusia; 


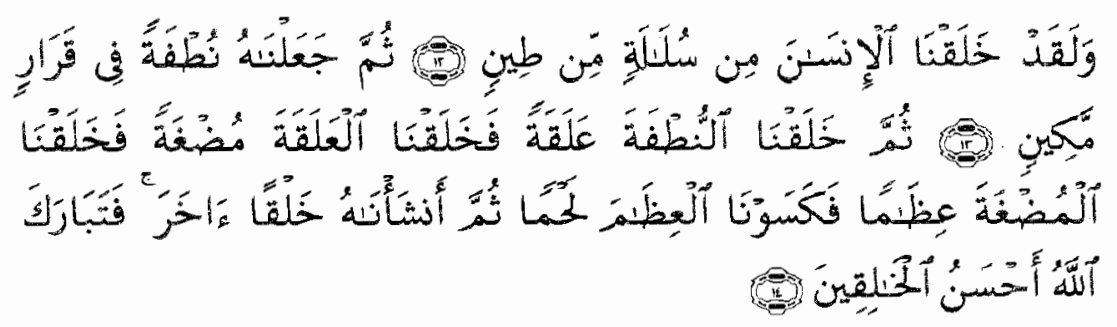

"Dan sesungguhnya Kami telah menciptakan manusia dari suatu saripati (berasal) dari tanah. Kemudian Kami jadikan saripati itu air mani (yang disimpan) dalam tempat yang kokoh (rahim). Kemudian air mani itu Kami jadikan segumpal darah, lalu segumpal darah itu Kami jadikan segumpal daging, dan segumpal daging itu Kami jadikan tulang belulang, lalu tulang belulang itu Kami bungkus dengan daging. Kemudian Kami jadikan dia makhluk yang (berbentuk) lain. Maka Maha sucilah Allah, Pencipta yang paling baik" (QS. al-Mu'minuun: 12-14).

Kata nutfah dalam surat al-Mu'minuun ayat ke-13 berarti campuran antara setetes mani laki-laki dan perempuan, sedangkan kata 'alaqoh memiliki 3 makna, yaitu lintah, sesuatu yang tergantung, dan segumpal darah. Dengan mencermati makna 'alaqoh (sesuatu yang tergantung) jika dikaitkan dengan embriologi manusia, dapat diamati pada penempelan (implantasi) embrio pada dinding rahim ibu. Arti segumpal darah dapat diamati pada perkembangan selanjutnya yang melibatkan pembentukan darah pada pembuluh tertutup sampai siklus metabolisme selesai di plasenta. Selama tahapan 'alaqoh, embrio memiliki penampakan seperti gumpalan darah. Kata mudghah dalam surat al-Mu'minuun ayat ke-14 berarti janin. Pada tahapan ini janin telah mengalami pertumbuhan dan perkembangan yang sangat cepat dan berlangsung serangkaian proses pembentukan organ untuk menjadi bentuk yang lebih sempurna. Maha benar Allah swt yang telah menurunkan alQur'an dengan ilmunya.

Melalui konsep embriologi yang tersurat di dalam al-Qur'an dapat dipelajari bahwa Allah swt menciptakan manusia melalui beberapa proses untuk memperoleh bentuk yang sempurna. Proses penciptaan ini mempunyai bahan dasar yang berasal dari tanah kemudian mengalami sejumlah proses

Ulul Albab, Vol. 8 No. 2, 2007 
menjadi bentuk yang sempurna. Penciptaan manusia berikutnya diciptakan dari air mani yang kemudian dipertemukan dengan "benih" perempuan. Melalui proses yang rumit, embrio tersebut bermigrasi dan kemudian tertanamlah "benih" manusia tersebut pada tempat yang kokoh, yaitu rahim. Seiring dengan berkembangnya ilmu pengetahuan di bidang embriologi, terdapat beberapa teori tentang perkembangan (embriologi) manusia sebelum al-Qur'an diturunkan, antara lain teori yang dikemukakan oleh Aristoteles (322.384 SM) yang menjelaskan bahwa penciptaan manusia berasal dari mani laki-laki dan wanita kemudian berkembang menjadi makhluk kecil yang menyerupai manusia. Teori ini bertahan selama 2000 tahun. Teori ini ditinggalkan karena muncul penemuan dari Fransisco Redi (1668 M) dan Louis Pasteur (1864 M) yang menjelaskan terbentuknya janin melalui embriologi modern. Penemuan pada abad ke-19 ini telah mendukung konsep embriologi yang ada di dalam al-Qur'an yang diwahyukan Allah swt kepada Nabi Muhammmad saw pada abad ke-7 M.

Firman Allah swt dalam al-Qur'an:

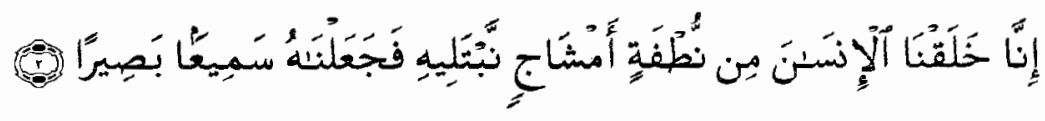

"Sesungguhnya Kami telah menciptakan manusia dari seteres mani yang bercampur yang Kami hendak mengujinya (dengan perintah dan larangan), karena Kami jadikan dia mendengar dan melihat" (QS. al-Insaan: 2).

Ayat ini menjelaskan bahwa penciptaan manusia terjadi melalui proses pertemuan antara setetes mani laki-laki dengan wanita. Dari hasil pertemuan tersebut dihasilkan sebuah sel yang berbentuk bulat. Menurut embriologi modern sel ini disebut zigot. Setelah zigot membelah menjadi 2 sel, selanjutnya sel tersebut akan mengalami serangkaian pembelahan mitosis. Proses pembelahan ini mengakibatkan bertambahnya jumlah sel dengan cepat (Sadler, 1997: 29-33). 
Pada abad pertengahan, al-Qur'an yang dibawa Rasulullah saw membuka pintu kegelapan teori embriologi sebelumnya dengan mengemukakan bukti-bukti penciptaan manusia yang sangat kompleks dan menyeluruh. Maha Benar Allah swt dengan segala firman-Nya yang merupakan sumber dari segala sumber ilmu, termasuk embriologi. Bukti-bukti tersebut tersurat dalam al-Qur'an. Allah swt berfirman:

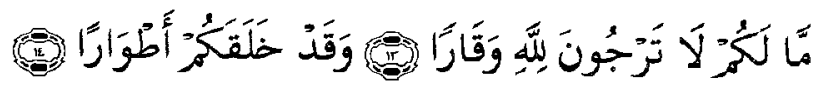

"Mengapa kamu tidak percaya akan kebesaran Allah? Padahal Dia sesungguhnya telah menciptakan kamu dalam beberapa tingkatan kejadian" (QS. Nuh: 13-14).

"Tingkatan kejadian" dalam surat Nuh: 13-14 menjelaskan tentang tingkatan-tingkatan (tahap-tahap) penciptaan manusia yang tersurat dalam surat al-Mu'minuun ayat 12-14.

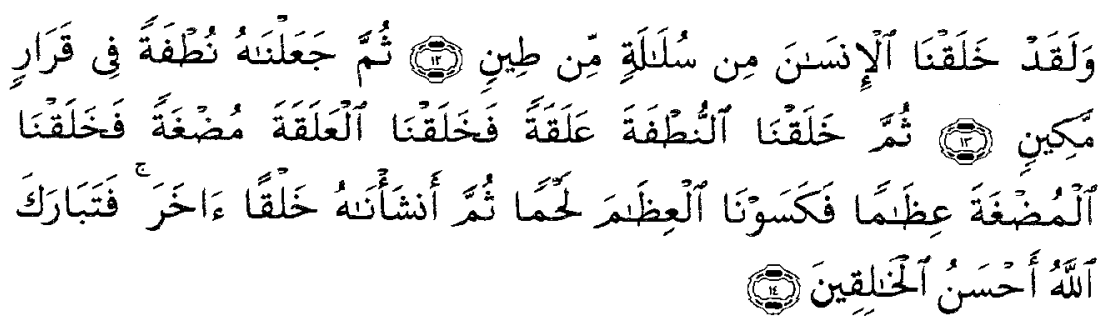

"Sesungguhnya Kami telah menciptakan manusia dari suatu saripati (berasal) dari tanah. Kemudian Kami jadikan saripati itu air mani (yang disimpan) dalam tempat yang kokoh (rahim). Kemudian air mani itu Kami jadikan segumpal darah, lalu segumpal darah itu Kami jadikan segumpal daging, dan segumpal daging itu Kami jadikan tulang belulang, lalu tulang belulang itu Kami bungkus dengan daging. Kemudian Kami jadikan dia makhluk yang (berbentuk lain). Maha Suci Allah, Pencipta Yang Paling Baik" (QS. al-Mu'minuun: 12-14).

Ulul Albab, Vol. 8 No. 2, 2007 
Dalam ayat yang lain juga disebutkan:

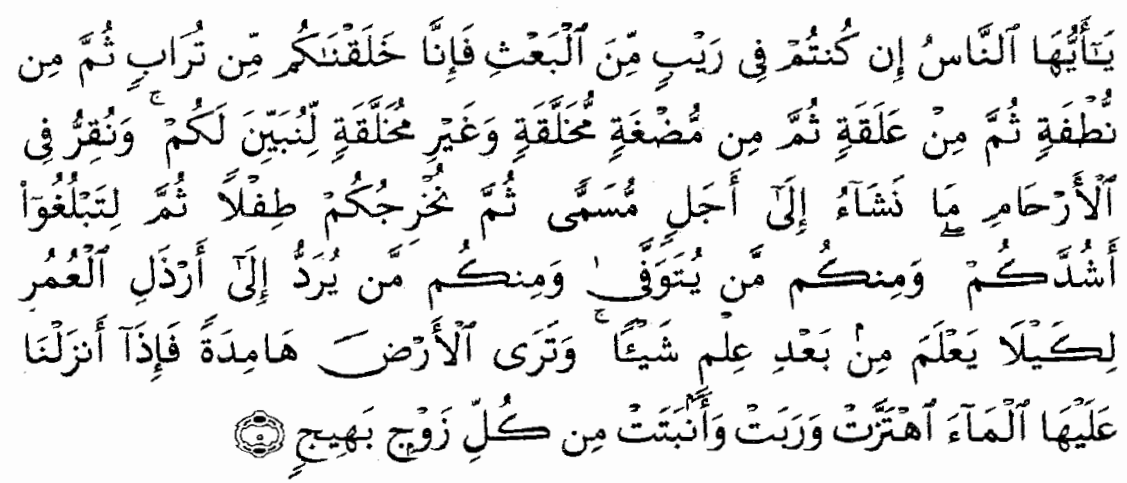

"Hai manusia, jika dalam keraguan tentang kebangkitan (dari kubur), maka (ketahuilah) sesungguhnya Kami telah menjadikan kamu dari tanah, kemudian dari setetes mani, kemudian dari segumpal darah, kemudian dari segumpal daging yang sempurna kejadiannya dan yang tidak sempuma, agar Kami jelaskan kepada kamu. Kami tetapkan dalam rahim, apa yang Kami kehendaki sampai waktu yang sudah ditentukan. Kemudian Kami keluarkan kamu sebagai bayi, kemudian (dengan berangsur-angsur) kamu sampailah pada kedewasaan. Diantara kamu ada yang diwafatkan dan (ada pula) diantara kamu yang dipanjangkan umurnya sampai pikun, supaya dia tidak mengetahui lagi sesuatupun yang dahulunya telah diketahuinya" (QS. al-Hajj: 5).

Dalam ayat tersebut telah dikemukakan konsep embriologi dalam al-Qur'an dan telah dibuktikan melalui hasil penelitian pada abad ke-19 oleh seorang ilmuwan bernama Wolf. Dari hasil penelitian tersebut dilaporkan bahwa proses penciptaan manusia terjadi melalui beberapa tahapan. Dalam penelitian selanjutnya Wolf menemukan saluran di dalam ginjal janin yang disebut duktus Wolfii.

Maha Benar Allah swt dalam segala firman-Nya, yang telah mewahyukan al-Qur'an kepada Nabi Muhammad saw, sebagai nabi terakhir untuk seluruh umat. Wahyu tersebut dapat dibuktikan sepanjang zaman. Lahirnya penemuan para ahli embriologi semakin membuktikan bahwa al-Qur'an merupakan sumber dari segala sumber ilmu. Di dalam ayat-ayat al-Qur'an terkandung konsep yang menjadi dasar konsep embriologi modern.

Ulul Albab, Vol. 8 No. 2, 2007 


\section{Konsep Embriologi Manusia Dalam Al-Qur'an}

Embriologi adalah ilmu yang mempelajari perkembangan janin. Berkaitan dengan hal ini dalam al-Qur'an telah dijelaskan bahwa perkembangan manusia di dalam rahim ibu melibatkan 3 proses, yaitu:

\section{Nutfah}

Nutfah merupakan pencampuran antara setetes mani laki-laki dan wanita. Setetes mani (dalam ilmu reproduksi disebut sperma) mengandung jutaan sel spermatozoa yang bercampur dengan sel telur (dalam ilmu reproduksi disebut ovum). Sebagaimana firman Allah swt:

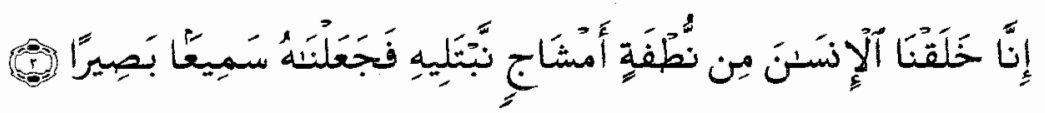

"sesungguhnya Kami telah menciptakan manusia dari setetes mani yang bercampur" (QS. al-Insaan: 2).

Bercampur di sini berarti pengerubungan sel-sel spermatozoa terhadap sel telur dan satu dari spermatozoa masuk ke dalam inti telur. Setelah terjadi pencampuran selanjutnya terjadi peleburan di antara keduanya. Pada proses ini terjadi penetrasi (penembusan) sel spermatozoa yang berhasil mencapai sel telur. Pencampuran ini disebut dengan proses fertilisasi yang terjadi pada tuba falopii dan akhirnya menghasilkan zigot. Pada saat ini Allah swt menentukan jenis kelamin janin sebagai takdir dari-Nya. Takdir ini terkait dengan penentuan jenis kelamin. Maha Benar Allah swt dalam segala firman-Nya:

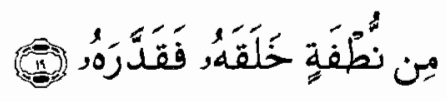

"Dari setetes mani, Allah menciptakannya lalu menentukannya" (QS. 'Abasa: 19)

Berdasarkan surat 'Abasa ayat ke-19 di atas telah dipelajari dalam ilmu genetika bahwa air mani (sperma) mengandung kromosom X dan $\mathrm{Y}$,

Ulul Albab, Vol. 8 No. 2, 2007 
sedangkan sel telur menghasilkan kromosom $X$ saja. Ketika X bertemu dengan Y, maka akan terbentuk jenis kelamin laki-laki $(X Y)$; sedangkan jika $X$ bertemu dengan $X$ akan menghasilkan jenis kelamin wanita (XX). Saat terjadi pembuahan (melibatkan pertemuan antara kromosom dari pihak laki-laki dan perempuan yang masing-masing terdiri dari 23 pasang). Pada sel telur yang telah dibuahi (zigot) turut berperan dalam menentukan jenis kelamin janin. Jenis kelamin setiap insan merupakan hasil campuran kromosom laki-laki dan perempuan. Kromosom manusia terdiri dari 23 pasang yang tersusun dari 22 pasang kromosom tubuh (autosom) dan 1 pasang kromosom kelamin (gomosom) (Rose-Neil, 2001: 38). Kromosom kelamin inilah yang berperan dalam menentukan jenis kelamin.

Pada proses perkembangan sperma di dalam testis, saat kromosom membelah; sperma memproduksi kromosom $X$ dan $Y$ dengan jumlah yang relatif seimbang. Jika sperma (berkromosom $X$ ) berhasil membuahi sel telur (berkromosom $\mathrm{X}$ ), maka akan diperoleh embrio berjenis kelamin perempuan; sebaliknya jika sperma yang berkromosom $Y$ membuahi sel telur yang berkromosom $\mathrm{X}$, maka akan diperoleh embrio berjenis kelamin laki-laki (XY). Dari keterangan ini jelaslah bahwa kromosom kelamin dari ayah yang menentukan jenis kelamin embrio dan janin sesuai dengan yang ditakdirkan Allah swt.

\section{Organogenesis (proses pembentukan organ)}

Proses pembentukan organ dimulai dari:

a. Pembentukan segumpal darah ('alaqoh). Pembentukan 'alaqoh terjadi setelah proses peleburan antara sel spermatozoa dengan sel telur kemudian terbentuklah zigot (merupakan cikal bakal manusia). Konsep embriologi di dalam al-Qur'an ini telah dipelajari dalam embriologi modern yang mengungkap bukti perjalanan zigot yang dalam perkembangan selanjutnya menjadi embrio kemudian menuju ke dinding rahim. Zigot akan membelah membentuk embrio dan 
mengalami beberapa kali pembelahan. Dalam proses pembelahan ini juga diiringi dengan perjalanannya menuju ke rahim sebagai tempat yang kokoh untuk melekatnya embrio. Di dalam rahim inilah embrio berkembang menjadi janin. Allah swt berfirman:

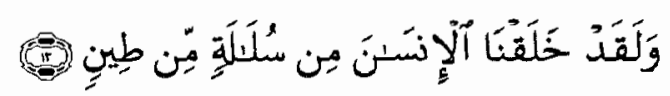

"Dan Sesungguhnya Kami telah menciptakan manusia dari suatu saripati (berasal) dari tanah" (QS. al-Mu'minuun: 12).

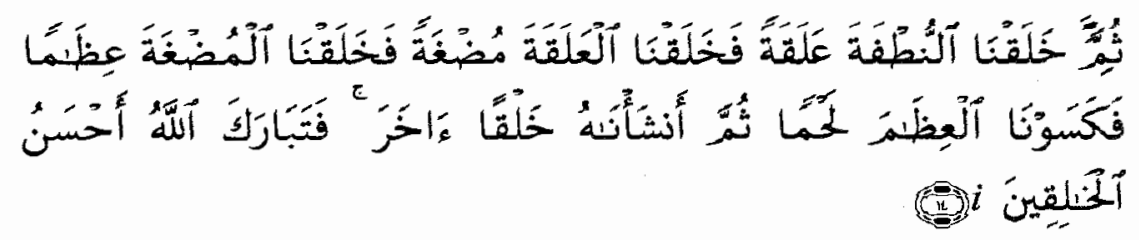

"Kemudian air mani itu kami jadikan segumpal darah" (QS. alMu'minuun: 14).

Pada abad ke-20 telah dilakukan penelitian yang mengungkap perjalanan sel telur yang telah dibuahi. Segera setelah inti sperma dan sel telur melebur saat pembuahan membentuk zigot, maka selanjutnya hasil zigot tersebut membelah diri menjadi 2 sel. Untuk tumbuh menjadi embrio, dibutuhkan waktu kurang lebih 30 jam setelah ovulasi. Sel-sel tersebut terus berkembang dan bergerak menuruni tuba falopii menuju ke rongga uterus atau rahim (Rose-Neil, 2001: 39).

Selanjutnya, sel-sel tersebut terus membelah hingga menghasilkan banyak sel dengan ukuran yang semakin kecil (disebut blastomer). Blastula tersebut terus mengadakan perkembangan membentuk momula kira-kira 60 jam setelah ovulasi. Morula yang mirip dengan buah murbei ini akan bergerak secara perlahan-lahan menuju ke dinding rahim untuk melakukan penempelan (implantasi). Implantasi tersebut terjadi secara alami dan tidak ditolak oleh tubuh ibu karena adanya enzim-enzim khusus yang dikeluarkan oleh embrio.

Ulul Albab, Vol. 8 No. 2, 2007 
b. Pembentukan segumpal daging (mudhghah), dalam bahasa Indonesia disebut mudigah. Bentukan yang menyerupai segumpal daging ini terjadi pada minggu ke-3 hingga ke-8. Sebagaimana firman Allah swt:

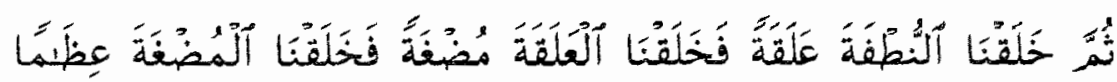

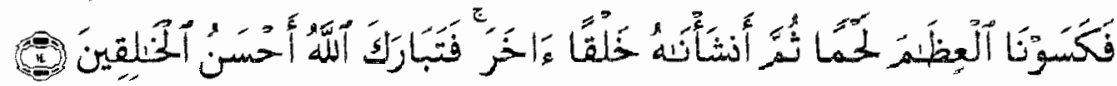
"....Lalu segumpal darah itu Kami jadikan segumpal daging...." (QS. al-Mu'minuun: 14).

c. Pembentukan tulang dan daging (dalam biologi disebut otot). Pada tahap ini rangka manusia mulai dibentuk. Rangka ini terdiri dari tulang-tulang yang kemudian dibungkus dengan daging (otot). Pada tahap ini manusia telah mempunyai bentuk yang sempurna secara fisik. Hal ini sesuai dengan firman Allah swt:

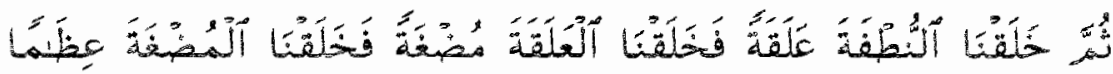

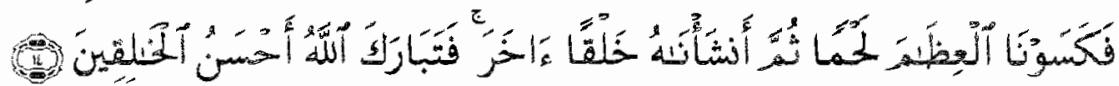
“...Dan segumpal daging itu Kami jadikan tulang belulang, lalu tulang belulang itu Kami bungkus dengan daging..." QS. (al-Mu'minuun: 14).

\section{Tahap perkembangan}

Tahap ini dimulai sejak minggu ke-8 yang telah menggambarkan kesempurnaan organ melalui organogenesis (proses pembentukan organ) (Poernomo, 1999: 1-7). Dalam hal ini telah terlihat beberapa anggota badan dan jenis kelamin. Keadaan ini akan terus mengalami perkembangan hingga menjelang kelahiran, seperti yang tersurat di dalam firman Allah swt:

Ulul Albab, Vol. 8 No, 2, 2007 


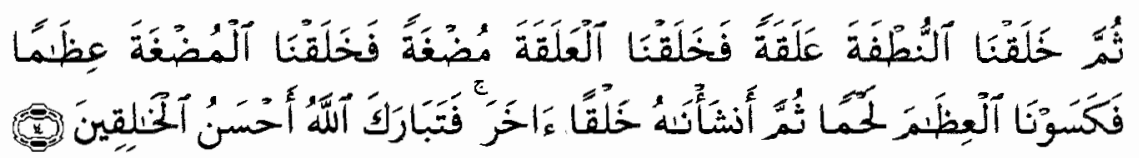

"Kemudian Kami jadikan dia makhlukyang (berbentuk) lain" (QS. al-Mu'minuun: 14).

Berdasarkan ayat tersebut, setelah manusia dilahirkan dari rahim ibunya untuk menjalani kehidupan di dunia, ia bertanggung jawab kepada Sang Pencipta, Allah swt. Hal ini dapat dipahami karena dalam mengarungi kehidupan harus disertai dengan pertanggungjawaban baik kepada Allah swt maupun kepada sesama manusia untuk menghasilkan keturunan berikutnya. Hal ini sesuai dengan firman Allah swt:

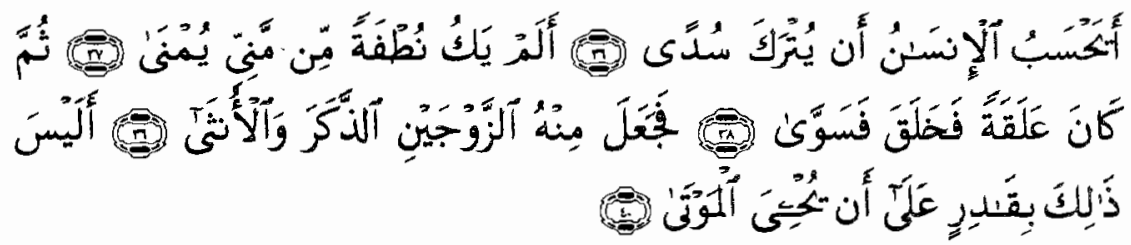

"Apakah manusia mengira bahwa ia akan dibiarkan begitu saja (tanpa pertanggungjawaban)? Bukankah ia dahulu adalah setetes mani yang ditumpahkan (ke dalam rahim), kemudian mani itu menjadi segumpal darah, lalu Allah menciptakannya, dan menyempurnakannya, lalu Allah menjadikan daripadanya sepasang laki-laki dan wanita. Bukankah (Allah yang berbuat) demikian berkuasa (pula) menghidupkan orang mati?" (QS. al-Qiyaamah: 36-40).

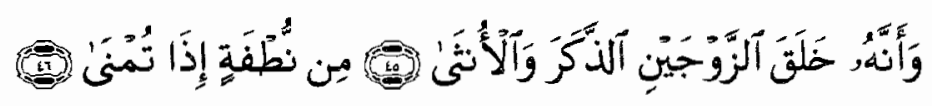

"Dialah yang menciptakan berpasang-pasangan laki-laki dan wanita, dari air mani, apabila dipancarkan" (QS. an-Najm: 45-46).

Ini juga didukung oleh ayat yang lain sebagaimana firman Allah swt:

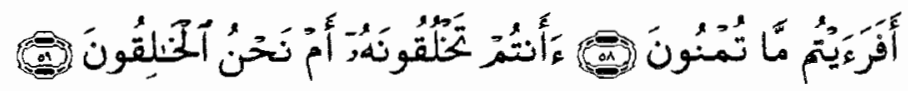

Ulul Albab, Vol. 8 No. 2, 2007 
"Maka terangkanlah kepada-Ku tentang nutfah yang kamu pancarkan. Kamukah yang menciptakannya, atau Kamikah yang menciptakannya?" (QS. al-Waaqi'ah: 58-59).

Ketiga ayat tersebut menjelaskan tentang peran setetes air mani dalam menentukan jenis kelamin pada manusia. Di dalam al-Qur'an Allah swt telah memberikan dasai-dasar informasi ilmiah bahwa jenis kelamin manusia ditentukan oleh air mani laki-laki yang terpancar. Hal ini dapat dibuktikan oleh ilmu pengetahuan terkait (genetika) yang mempelajari perkelaminan. Dalam hal ini air mani (sel spermatozoa) mengandung kromosom $\mathrm{X}$ dan $\mathrm{Y}$ yang kemudian akan bercampur dengan sel telur wanita yang mengandung kromosom $\mathrm{X}$.

Dalam ayat al-Qur'an telah ditegaskan bahwa sel spermatozoa merupakan bagian dari air mani. Dalam kajian ilmiah modern yang telah berkembang pada abad ke-19 telah terungkap bahwa air mani (sperma) terdiri dari beberapa komponen, antara lain adalah cairan (yang dihasilkan oleh kelenjar asesoris) dan sel-sel spermatozoa (Hafez, 1993: 165). Dari setetes air mani yang dipancarkan ternyata hanya sebagian kecil saja yang dapat menuju sel telur (ovum). Hasil penelitian membuktikan bahwa satu sel spermatozoa saja yang mampu membuahi sel telur setelah melalui berbagai seleksi dan kompetisi, Allah swt berfirman:

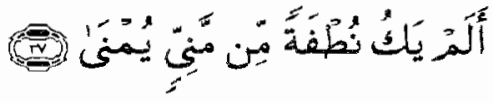

"Bukankah ia dahulu setetes mani yang ditumpahkan (ke dalam rahim)?" (QS. al-Qiyaamah: 37).

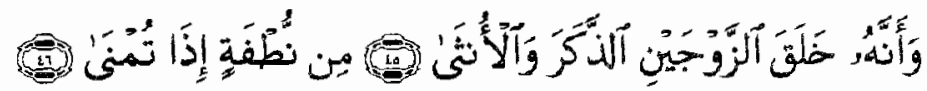

"Dialah yang menciptakan berpasang-pasangan laki-laki dan wanita, dari air mani, apabila dipancarkan" (QS. al-Najm: 45-46). 


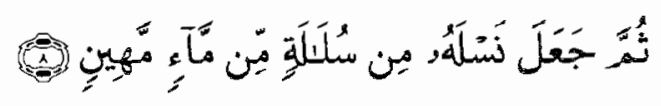

"Kemudian Dia menjadikan keturunannya dari saripati air yang hina (air mani)" (QS. as-Sajadah: 8).

Al-Qur'an tidak menyebutkan secara khusus tentang air mani wanita (saat ini disebut ovum/sel telur) tetapi al-Qur'an telah menyebutkan air mani yang tercampur. Ini merupakan peluang untuk mencari tahu bagi orang-orang yang berpikir. Allah swt menjelaskan dalam firmanNya;

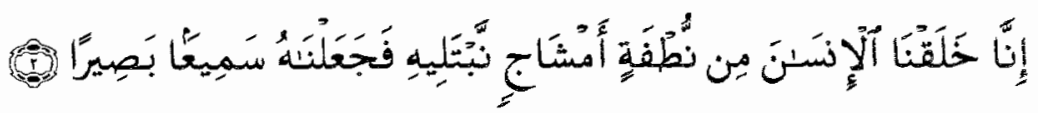

"Sesungguhnya Kami telah menciptakan manusia dari setetes mani yang bercampur yang Kami hendak mengujinya (dengan perintah dan larangan), karena itu Kami jadikan dia mendengar dan melihat" (QS. al-Insaan: 2).

\section{Kesimpulan}

Dari hasil penelitian ini dapat disimpulkan bahwa embriologi manusia telah dipelajari ilmuwan selama beberapa abad, tetapi belum dapat menjelaskan secara detail tentang proses terbentuknya manusia; kadangkadang teori yang dikemukakan bertentangan dengan fakta. Hal ini disebabkan karena keterbatasan ilmu dan pengetahuan yang dimiliki oleh manusia.

Jauh sebelum manusia melakukan penelitian, al-Qur'an telah menjelaskan secara detail tentang bagaimana Allah SWT menciptakan manusia. Dalam surat al-Mu'minuun ayat 12-14 telah dijelaskan bahwa Allah menciptakan manusia melalui beberapa tahapan, antara lain manusia diciptakan dari suatu saripati (berasal) dari tanah, kemudian saripati itu dijadikan air mani (yang disimpan) di dalam tempat yang kokoh (rahim). Kemudian air mani itu dijadikan segumpal darah, lalu segumpal darah itu

Ulul Albab, Vol. 8 No. 2, 2007 
dijadikan segumpal dagaing, lan segumpal daging tersebut dijadikan tulang belulang yang akhirnya tulang-belulang ini dibingkus dengan daging.

Pada abad ke-20, baru dilakukan berbagai macam penelitian yang terkait dengan embriologi modern yang hasilnya mendukung pernyataan di dalam al-Qur'an surat al-Mu'minuun ayat 12-14. Hal ini dibuktikan dengan adanya fertilisasi, pembentukan zigot, kemudian zigot melakukan implantasi di dalam tempat yang kokoh (rahim), mulai terjadi organogenesis (proses pembentukan organ), yang diiringi dengan pertumbuhan dan perkembangan hingga saatnya dilahirkan.

\section{DAFTAR PUSTAKA}

Departemen Agama Repuplik Indonesia. 2005. Al-Qur'an dan Terjemahannya.

Hafez, ESE. 1993. Animal Reproduction. Philadelphia. Co. Ltd.

Janzen, H. H. 2004. Carbon Cycling in Earth Systems-a Soil Science Perspective. In agriculture, Ecosystems, and environment. (http://.wikipedia.org/ wiki/siklus).

Krauskopf, Konrad. B, dkk. 1993. The Physical Universe. New York: Mc. GRaw-Hill.

Poernomo, Bambang. 1999. Teratology High Light. Surabaya: Post Gtaduate Programme. Airlangga University.

Randall, David, dkk. 1997. Animal Physiology. New York: W H. Freeman and Company.

Rose-Neil, Wendy. 2001. Panduan Lengkap Perawatan Kehamilan. Penerjemah: Biro Penerjemah PP Jakarta: Jakarta: Dian Rakyat.

Sadler, T.W. 1997. Embriologi Kedokteran Langman. Jakarta: EGC. Sudarmadji, Slamet, dkk. 1989. Analisa Bahan Makanan dan Pertanian. Yogyakarta: Liberty Yogyakarta.

Tamarin, Robert. H. 2002. Principles of Genetics. New York: McGraw-Hill. 